Annals of Warsaw University of Life Sciences - SGGW

Land Reclamation No 47 (1), 2015: 3-17

(Ann. Warsaw Univ. Life Sci. - SGGW, Land Reclam. 47 (1), 2015)

\title{
Nutrients availability and hydrological conditions of selected wetland ecosystems in the Biebrza river valley
}

\author{
MATEUSZ STELMASZCZYK ${ }^{1}$, TOMASZ OKRUSZKO ${ }^{2}$, PATRICK MEIRE $^{3}$ \\ ${ }^{1}$ Laboratory - Water Center, Warsaw University of Life Sciences - SGGW \\ ${ }^{2}$ Department of Hydraulic Engineering, Warsaw University of Life Sciences - SGGW \\ ${ }^{3}$ Department of Biology, Ecosystem Management Research Group, University of Antwerp (UIA)
}

\begin{abstract}
Nutrients availability and hydrological conditions of selected wetland ecosystems in the Biebrza river valley. Paper presents results of investigation of hydrological conditions and nutrients limitation and availability for wetland vegetation in selected sites within Biebrza river valley. Analysed sites were overgrown by tall sedge Magnocaricion vegetation (Caricetum gracilis and Caricetum elatae), wet meadow Molinio-Arrhenatheretea vegetation (Molinietum caeruleae), and sedge-moss Scheuchzerio-Caricetea nigrae vegetation (Caricetum lasiocarpae). There were noted a close relationship between vegetation types, hydrological regimes and kind of nutrient limitation. Low productive Molinio-Arrhenatheretea and Scheuchzerio-Caricetea nigrae vegetations fed mainly by groundwater were limited by phosphorus, while highly productive Magnocaricion vegetation, fed by river water, was subjected to nitrogen limitation. We have found big diversification of groundwater and surface water levels within habitats of different vegetation types along the Biebrza river valley. Magnocaricion vegetation present on flooded areas is characterized by significant water level fluctuations and long-lasting inundations. On areas covered by Molinio-Arrhenatheretea vegetation we noted majority of water levels not exceeding the level of the ground surface. Whereas Scheuchzerio-Caricetea nigrae vegetation, fed by groundwater, is characterized by low variation of groundwater levels.
\end{abstract}

Key words: wetlands, hydrological regimes, inundations, nutrients limitation, productivity, vegetation types

\section{INTRODUCTION}

Wetland ecosystems are exceptionally rich ecosystems with various degree of biodiversity. Vegetations in wetlands mainly depend on the source of the feeding water, soil characteristics, availability of nutrients and management, e.g. grazing, mowing (Koerselman et al. 1990, Koerselman et al. 1992, Boeye and Verheyen 1994). Hydrological conditions and limiting nutrient concept are considered to be main forces in ecosystem development (Olde Venterink et al. 2009). Therefore the $\mathrm{N}: \mathrm{P}$ is used as an indicator to determine which nutrient is limiting the growth of the vegetation (Güsewell and Koerselman 2002). The $\mathrm{N}$ : P below 14 indicates nitrogen limitation, the $\mathrm{N}$ : $\mathrm{P}$ above 16 phosphorus limitation, and between 14 and 16 situation when plant growth is co-limited by $\mathrm{N}$ and $\mathrm{P}$ together (Koerselman and Meuleman 1996).

Human can induces changes in the environment, and one of the directions of that kind of changes in the environment can be degradation. We should restore areas degraded by human impact and further protect them. In order 
to keep wetlands in good status, we need to monitor factors responsible for wetlands conditions in natural areas to implement achieved knowledge about relations in the ecosystems in protection and restoration projects. Such kind of area is Biebrza National Park with its valuable feature of perfectly formed and well-preserved diagonal and longitudinal wetland ecosystems zonation (Wassen et al. 2002).

In this paper authors focused on obtaining a standardized dataset of interactions between vegetation, ground- and surface-water supply characteristic, and nutrient availability for plants. This type of dataset plays a crucial role in projects focused on restoration and conservation of wetland habitats. The managers of nature reserves involved in restoration projects try to solve water pollution problems, acidification and eutrophication, and at the same time they try to understand the anthropogenic changes (positive and negative) which all is impossible without previous understanding of interactions between main factors forming wetlands habitats (Schrautzera et al. 2013).

\section{MATERIAL AND METHODS}

\section{Study design}

As a study area Biebrza National Park (BNP) located in north-east part of Poland, was chosen. BNP established in 1993 is the biggest among Polish national parks, and the main task of the Park is to protect the variety of species of fauna and flora within the existing wetland eco- systems, including various kinds of peat and peat bogs, shaped by the Biebrza river. Elaborate wetland ecosystems of the Biebrza River valley can exist only if proper habitats are maintained, which could not be done before its previous complex monitoring.

For paper purposes monitoring network was established which comprise of 16 plots located within five sites along Biebrza river valley (Table 1). The sites were chosen due to their natural character and occurrence of one of the vegetation types: tall sedge Caricetum gracilis and Caricetum elatae, wet meadow Molinietum caeruleae, and sedge-moss Caricetum lasiocarpae. Analysed sites were selected to represent a hydrological gradient: from groundwater fed to river water supply, and soils having different properties of retention and susceptibility to overdrying. Thickness of peat in Lipsk and as well in Bagno Lawki site was the largest among studied areas, respectively 3 to $5 \mathrm{~m}$ and 2 to $3 \mathrm{~m}$. In Lipsk site peat had low degree of mineralization and fibrous or spongy texture. In Bagno Lawki site slightly worst properties were present, medium degree of mineralization and amorphous or fibrous texture. In Mścichy and Olszowa Droga sites peat layer had thickness of maximum 1.5 to $2 \mathrm{~m}$, and was laid on light sands. In both areas peat layer had mainly medium degree of decomposition and amorphous or fibrous texture. Peat layer in Kuligi site was comparatively thin - did not exceed 0.8 to $1.5 \mathrm{~m}$, and was situated on light formations - light sands. Strong degree of decomposition as well as an 
TABLE 1. Characteristic of study set-up

\begin{tabular}{|c|c|c|c|c|c|}
\hline Site name & Plot name & $\begin{array}{c}\text { Number of } \\
\text { individual } \\
\text { species }\end{array}$ & Plant community & Vegetation type & $\begin{array}{c}\text { Type of } \\
\text { water supply }\end{array}$ \\
\hline \multirow{2}{*}{ Lipsk } & PLP1 & 31 & \multirow{3}{*}{$\begin{array}{l}\text { Caricetum } \\
\text { lasiocarpae }\end{array}$} & \multirow{3}{*}{$\begin{array}{c}\text { Scheuchzerio- } \\
\text {-Caricetea nigrae } \\
\text { (sedge-moss) }\end{array}$} & \multirow{10}{*}{$\begin{array}{l}\text { groundwater } \\
\text { supply }\end{array}$} \\
\hline & PLP2 & 29 & & & \\
\hline \multirow{5}{*}{ Bagno Ławki } & BL1D & 25 & & & \\
\hline & BL2 & 23 & \multirow{4}{*}{$\begin{array}{l}\text { Caricetum elatae } \\
\text { (mossy variant) }\end{array}$} & \multirow{4}{*}{$\begin{array}{l}\text { Magnocaricion (mos- } \\
\text { sy variant) (tall sedge } \\
\text { - succession from } \\
\text { sedge-moss) }\end{array}$} & \\
\hline & BL3 & 27 & & & \\
\hline & BL4 & 17 & & & \\
\hline & BL6 & 24 & & & \\
\hline \multirow{3}{*}{ Kuligi } & KUL2D & 27 & \multirow{3}{*}{$\begin{array}{l}\text { Molinietum } \\
\text { caeruleae }\end{array}$} & \multirow{3}{*}{$\begin{array}{c}\text { Molinio- } \\
\text {-Arrhenatheretea } \\
\text { (wet meadow) }\end{array}$} & \\
\hline & KUL3 & 20 & & & \\
\hline & KUL4 & 17 & & & \\
\hline \multirow{4}{*}{ Mścichy } & MS2 & 14 & \multirow{3}{*}{$\begin{array}{l}\text { Caricetum } \\
\text { gracilis }\end{array}$} & \multirow{6}{*}{$\begin{array}{l}\text { Magnocaricion } \\
\text { (tall sedge) }\end{array}$} & \multirow{6}{*}{$\begin{array}{l}\text { river inunda- } \\
\quad \text { tion }\end{array}$} \\
\hline & MS3D & 17 & & & \\
\hline & MS4 & 20 & & & \\
\hline & MS5 & 11 & \multirow{3}{*}{ Caricetum elatae } & & \\
\hline \multirow{2}{*}{ Olszowa Droga } & OD2 & 22 & & & \\
\hline & OD3D & 19 & & & \\
\hline
\end{tabular}

amorphous and chunky texture characterizes peat from this area. Often bottom part of peat layer was significantly silted (Banaszuk 2000). In each plot a piezometer was installed for groundwater monitoring purpose. Additionally vegetation composition according to BraunBlanquet scale and vegetation productivity were studied. Moreover to have clear characteristic of habitats of typical plant communities, $\mathrm{N}$ and $\mathrm{P}$ concentrations in vegetation biomass were studied.

\section{Groundwater monitoring}

For groundwater monitoring purpose a network of piezometers were established and installed along Biebrza river valley. Locations of piezometers were chosen in a view of occurrence of analysed vegetation types. Each piezometer was anchored in the mineral layer, laid under top peat layer. Electronic devices to permanent measurement of groundwater level changes (D-divers) were installed in selected piezometers (one piezometer with D-diver per site). In this paper we present results of water levels measurements done by D-divers, programmed with 6-hour interval of measurement time.

\section{Vegetation}

To have an overview about present vegetation, species richness and composition was recognized. For that purpose full recordings of vegetation relevés according to Braun-Blanquet scale (1951) (species, cover, abundance, height etc.) were done. This recognition was done in the middle of June 2004. Nearby each piezometer or even often typical square of $10 \mathrm{~m}$ was chosen and vegetation was recognized. 
In order to obtain information about productivity of different plant communities aboveground biomass was sampled. In chosen plots, vegetation samples were taken in squares of $50 \mathrm{~cm}$. Sampling of vegetation was carried out in the peak of vegetation grow. Five replicates of vegetation samples were taken in each plot. In each square aboveground vegetation was cut $2 \mathrm{~cm}$ above a soil surface and divided to living and dead part of biomass. Aboveground vegetation was dried at $75^{\circ} \mathrm{C}$ for $48 \mathrm{~h}$, and weighted. The samples were subjected to digestion with sulphiric acid and hydrogen peroxide mixture (Houba et al. 1989). Then phosphorus and nitrogen concentrations in dry weight of living part of biomass were determined colorimetrically using SKALAR segmented-flow analyzer. Next the N : P were calculated. In each plot five replicates were analysed. Most of the analyses were done in the laboratory of ECOBE (Ecosystem Management Research Group, University of Antwerp, Biology Department).

\section{Statistics}

To assess hierarchy of plant communities on the basis of species recognition from vegetation relevés a cluster analysis was performed. Ward's hierarchical clustering method was chosen and clustering was done using Statistica 8 program.

\section{RESULTS AND DISCUSSION}

\section{Vegetation characteristics}

In this paper we focused on three vegetation types which are: Magnocaricion vegetation (e.g. Caricetum gracilis and
Caricetum elatae in Mścichy and O1szowa Droga sites), Molinio-Arrhenatheretea vegetation (Molinietum caeruleae in Kuligi site), and Scheuchzerio-Caricetea nigrae vegetation (e.g. Caricetum lasiocarpae in Lipsk and Bagno Lawki sites). In total we noted 89 individual species in all vegetation relevés. Vegetation recognition showed that in Lipsk site all of the plots are situated in plant community of Carex lasiocarpa, the most biodiverse plant community among considered in this paper (more than 30 species in one relevé) (Table 1). Additionally this plant community was recognized in one plot from Bagno Ławki site. Caricetum elatae community (mossy variant, the early stage of succession from sedge-moss community) cover rest of locations in Bagno Ławki site. Species composition showed that mossy variant of Caricetum elatae present in Bagno Lawki site is more species reach than typical C. elatae plant community found in the rest of sites. Previously this area was overgrown by typical sedge-moss plant communities such as e.g. C. lasiocarpae (Pałczyński 1979, Matuszkiewicz et al. 2000) but our study showed change to tall sedge community. Present plant community was classified as tall sedge community from systematic point of view but species composition shows close relation to sedge-moss communities. This was confirmed by cluster analysis (Fig. 1) showing that plant community from Bagno Ławki site is closer to groundwater fed sedge-moss C. lasiocarpae and wet Molinion meadow than to Magnocaricion vegetation. Magnocaricion vegetation was the 


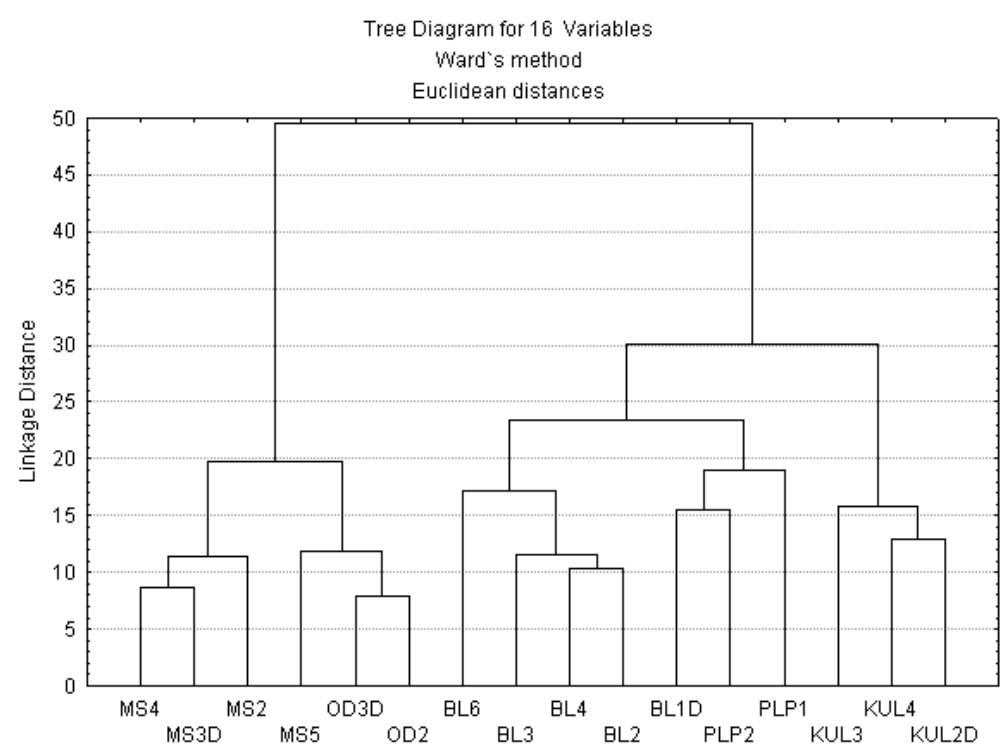

FIGURE 1. Dendrogram showing clustering of vegetation on the basis of species abundance in vegetation relevés

least diversified vegetation type among studied (C. gracilis and C. elatae) with member of individual species from 11 to 22. In Mścichy site one plot is located in Caricetum elatae plant community and the rest of plots are situated in Caricetum gracilis community. All of plots from Olszowa Droga site are overgrown by Caricetum elatae (Table 1).

\section{Vegetation productivity}

As it is shown on Figure 2, representing results of analysis of dry weight of aboveground living part of biomass, there is a variation of biomass production within considered vegetation tapes. The lowest productivity of vegetation types analysed in this paper is observed for Scheuchzerio-Caricetea nigrae vegetation (Caricetum lasiocarpae), and differs from 104.24 to $219.76 \mathrm{~g} \cdot \mathrm{m}^{-2}$ with mean value of $153.87 \mathrm{~g} \cdot \mathrm{m}^{-2}$. Mossy var- iant of Caricetum elatae from Bagno Ławki area is also very low productive. Dry weight differs from 153.84 to $322.92 \mathrm{~g} \cdot \mathrm{m}^{-2}$ with mean value of $256.76 \mathrm{~g} \cdot \mathrm{m}^{-2}$. These values aren't typical for tall-sedge vegetation such as Caricetum elatae (mossy variant) which was recognised on the area according to vegetation relevés. They indicate strict connection of this vegetation to its previous stadium of succession - sedge-moss vegetation type. Third low productive vegetation among considered vegetation types is Molinion meadow, with dry weight of biomass in a range between 135.60 and $259.20 \mathrm{~g} \cdot \mathrm{m}^{-2}$, and mean value of $210.47 \mathrm{~g} \cdot \mathrm{m}^{-2}$. The rest two vegetation types, both tall-sedges plant communities are high productive. Dry weight of living part of biomass for Caricetum elatae plant community shows the highest variability among analysed. The 


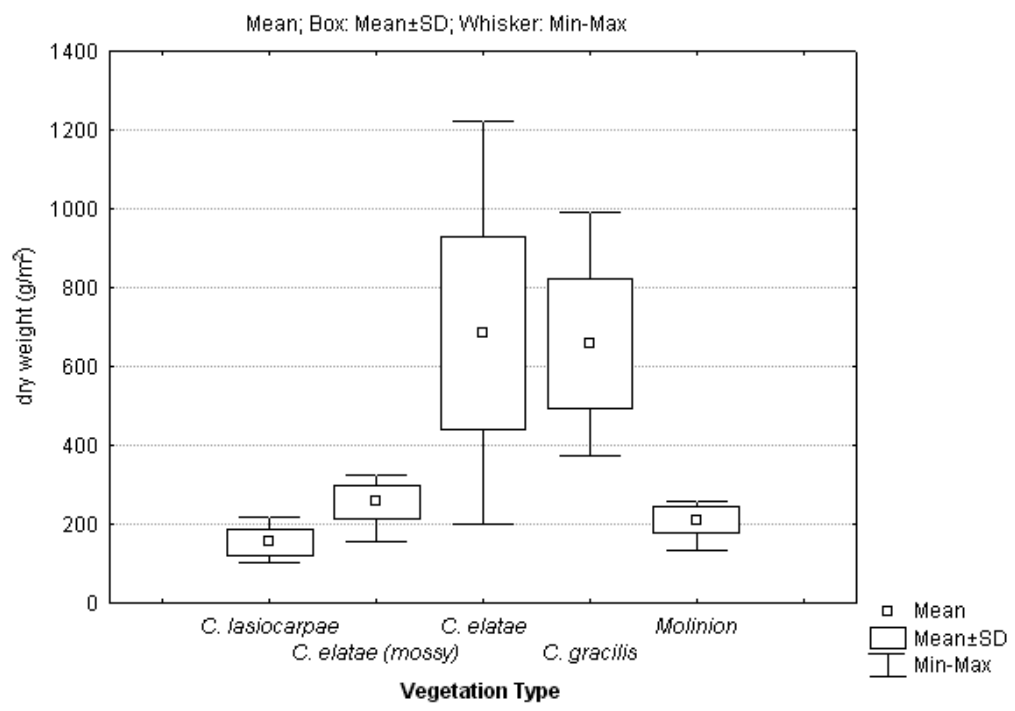

FIGURE 2. Dry weight of living part of biomass of chosen plant communities

lowest noted value is similar to values characteristic for low productive vegetation $\left(198.12 \mathrm{~g} \cdot \mathrm{m}^{-2}\right)$ while the highest is almost six times bigger $\left(1222.28 \mathrm{~g} \cdot \mathrm{m}^{-2}\right)$. The mean value equals $683.80 \mathrm{~g} \cdot \mathrm{m}^{-2}$ which confirm high productivity of this vegetation. Second high productive vegetation is Caricetum gracilis plant community, with similar mean value to the Caricetum elatae plant community $\left(657.40 \mathrm{~g} \cdot \mathrm{m}^{-2}\right)$ but with narrow range between minimal and maximal values (from 372.84 to $990.76 \mathrm{~g} \cdot \mathrm{m}^{-2}$ ).

\section{Water levels}

Meteorological conditions present during water levels monitoring were analysed based on data obtained from Biebrza meteorological station located in the middle of Biebrza valley. Total monthly rainfalls and average monthly temperatures for two hydrological years: 2003 and 2004 were taken into account in relation to averages from 35-year period 1976-2010 (Fig. 3). Frequency and volume of precipitation have significance for analysed vegetation types especially for those overgrowing locations far from the river. Heavy precipitation with at the same time fast surface runoff on the areas at the edge of the river valley leads to fast response in groundwater level changes. Presented two hydrological years characterize different periods, year 2003 was drier whereas year 2004 was more wet compared to multiyear average. Various conditions of water supply form a basis for recognition of monitoring period as an appropriate for defining water levels characteristic of analysed vegetation types. July was the hottest month during analysis period (average monthly temperature higher than $16^{\circ} \mathrm{C}$ ) whereas December, January and February characterizes the lowest temperatures, not exceeding $0^{\circ} \mathrm{C}$. High 


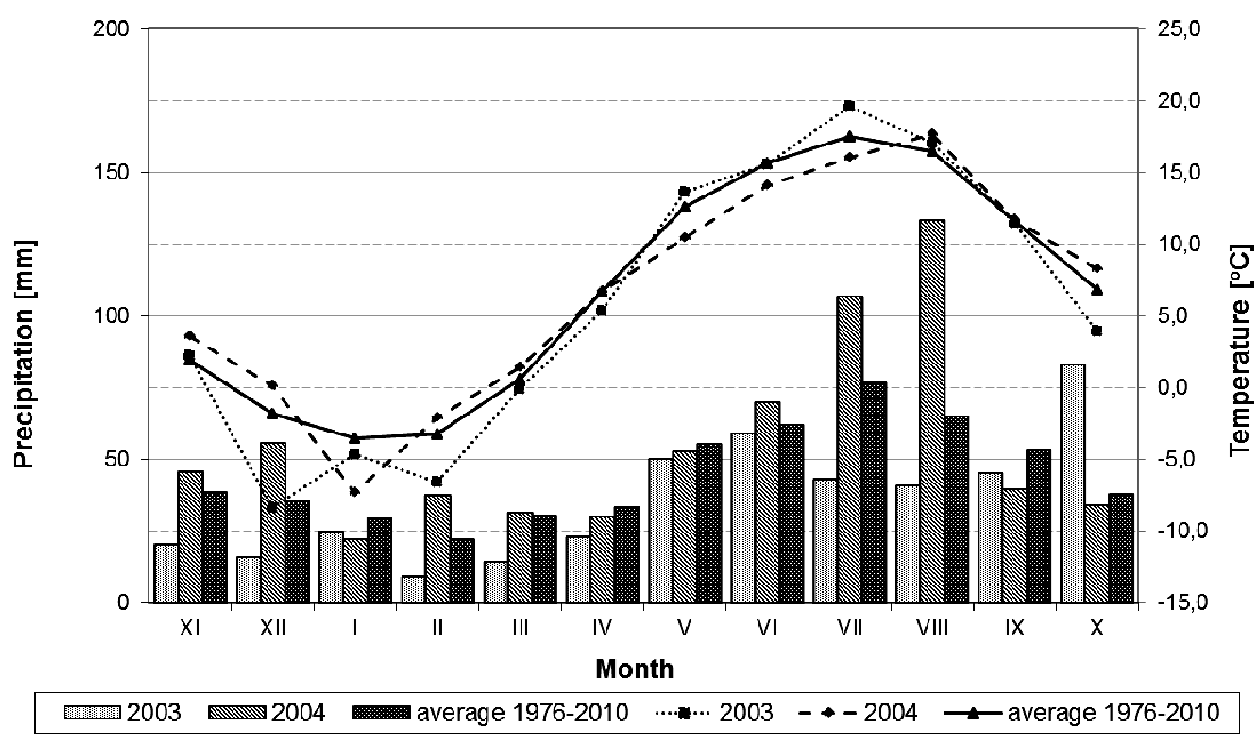

FIGURE 3. Total monthly rainfalls and average monthly temperatures for Biebrza meteorological station for two hydrological years: 2003 and 2004 in relation to averages from 1976-2010 period

temperatures and low precipitation during summer period can lead to lowering of ground water levels parallel with high evapotranspiration.

Results of water levels monitoring from 1 May 2003 till 30 April 2004 (Fig. 4 and Table 2) show a clear seasonal pattern with sharp decline from May onwards till late summer and higher water levels in winter period. The highest water level fluctuations and occurrence of long-lasting inundations were the most characteristic for Magnocaricion vegetation occurring in flooded areas. During most of the measurement time the water levels were higher then the ground level (more than $50 \%$ of time). In Mścichy site high inundation with water levels higher than $30 \mathrm{~cm}$ above ground surface was present continuously for nearly 150 days during the measurement period. In Olszowa Droga area quite high inundation with more than $20 \mathrm{~cm}$ above ground surface was present continuously for more than 100 days during the measurement period. Maximum inundation occurred on 16 February 2004, during this day water level was 67.4 and $43.5 \mathrm{~cm}$ above the ground surface, respectively in Mścichy and Olszowa Droga sites. Only in these sites, covered by Magnocaricion vegetation, water levels reached higher than $20 \mathrm{~cm}$ above the ground surface. Moreover we observed big diversification of water levels in these areas, contrary to high inundations the lowest water levels were observed in late summer and in early autumn. In Olszowa Droga site the lowest levels were observed at the end of August 2003 reaching $95.5 \mathrm{~cm}$ below ground surface on $30 \mathrm{Au}-$ gust. In Mścichy site maximum lowering of water table was observed on 30 September 2003 when water table reached $98.5 \mathrm{~cm}$ below ground surface. 
Water levels

01.05.2003 - 30.04.2004

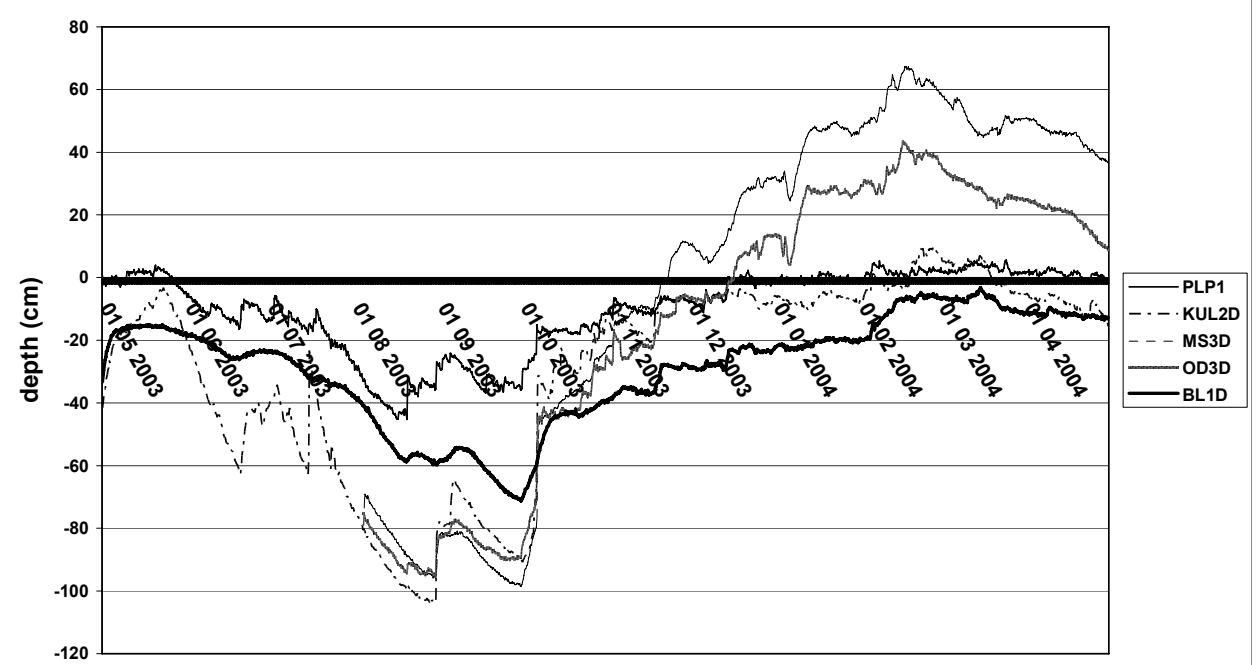

FIGURE 4. Water table level changes in studied sites (PLP1 - Scheuchzerio-Caricetea nigrae vegetation, KUL2D - Molinio-Arrhenatheretea vegetation, MS3D and OD3D - Magnocaricion vegetation, BL1D - Magnocaricion vegetation (mossy variant)

TABLE 2. Characteristic of water levels in analysed sites (minus means the water beneath the ground surface)

\begin{tabular}{|c|c|c|c|c|c|c|c|c|}
\hline \multirow[t]{2}{*}{$\begin{array}{l}\text { Localiza- } \\
\text { tion }\end{array}$} & \multirow[t]{2}{*}{ Vegetation type } & $\begin{array}{l}\text { Water } \\
\text { above }\end{array}$ & $\begin{array}{c}\text { Water } \\
\text { beneath }\end{array}$ & $\begin{array}{c}\text { Water } \\
\text { more than } \\
20 \mathrm{~cm} \\
\text { above }\end{array}$ & $\begin{array}{l}\text { Water } \\
\text { more than } \\
20 \mathrm{~cm} \\
\text { beneath }\end{array}$ & \multirow[t]{2}{*}{$\begin{array}{l}\text { Min } \\
(\mathrm{cm})\end{array}$} & \multirow[t]{2}{*}{$\begin{array}{l}\text { Max } \\
(\mathrm{cm})\end{array}$} & \multirow[t]{2}{*}{$\begin{array}{l}\text { Average } \\
(\mathrm{cm})\end{array}$} \\
\hline & & \multicolumn{2}{|c|}{$\begin{array}{l}\text { ground surface } \\
\text { (\% of time) }\end{array}$} & \multicolumn{2}{|c|}{$\begin{array}{c}\text { ground surface } \\
\text { ( } \% \text { of time) }\end{array}$} & & & \\
\hline Lipsk site & $\begin{array}{l}\text { Scheuchzerio- } \\
\text {-Caricetea nigrae }\end{array}$ & 31.9 & 68.1 & 0 & 17.4 & -45.3 & 5.6 & -8.8 \\
\hline Kuligi site & $\begin{array}{l}\text { Molinio- } \\
\text {-Arrhenatheretea }\end{array}$ & 7.3 & 92.7 & 0 & 42.3 & -103.9 & 9.8 & -27.9 \\
\hline $\begin{array}{l}\text { Mścichy } \\
\text { site }\end{array}$ & Magnocaricion & 66.4 & 33.6 & 52.7 & 27.57 & -98.5 & 67.4 & 4.3 \\
\hline $\begin{array}{l}\text { Olszowa } \\
\text { Droga site }\end{array}$ & Magnocaricion & 53.1 & 46.9 & 30.1 & 31.47 & -95.5 & 43.5 & -10.4 \\
\hline $\begin{array}{l}\text { Bagno } \\
\text { Lawki site }\end{array}$ & $\begin{array}{l}\text { Scheuchzerio- } \\
\text {-Caricetea nigrae }\end{array}$ & 0 & 100 & 0 & 54.8 & -71.3 & -3.2 & -26.2 \\
\hline
\end{tabular}

On areas covered by Molinio-Arrhenatheretea vegetation (Kuligi site) we noted majority of water levels not exceeding the level of the ground surface (about $90 \%$ of measurement time).
Studied area, with present Molinio-Arrhenatheretea vegetation is subjected to hydrological conditions slightly moderated by human, which leads to occurrence of diversified ground water levels. 
In Kuligi site we can observe fluctuations from very low levels in late summer and in early autumn to levels arranged on surface of the ground or nearly below it, occurring in winter and spring. During a measurement period big lowering of groundwater table was observed. Deep lowering with more than $60 \mathrm{~cm}$ beneath ground surface was present continuously for 73 days in the measurement period. The deepest level of groundwater table occurred on 28 August 2003, that day water level reached $103.9 \mathrm{~cm}$ below the ground surface. For most of the time water levels were observed on surface of the ground or nearly below it. There were no high inundations. Maximum level of water table was observed on 27 February 2004 and was situated $9.8 \mathrm{~cm}$ above the surface of the ground.

Scheuchzerio-Caricetea nigrae vegetation, fed by groundwater, is characterized by low variation of groundwater levels. In Lipsk site maximum level of water table was observed on 24 March 2004 and was situated $5.6 \mathrm{~cm}$ above the surface of the ground. During late summer and early autumn we observed the lowest groundwater levels however there was no big lowering of water levels observed. The lowest level of groundwater occurred on 19 August 2003, that day water level reached $45.3 \mathrm{~cm}$ beneath the ground surface. Lowering of water level bigger than $25 \mathrm{~cm}$ was present continuously for more than two months. On the Bagno Lawki site the lowering of water levels in late summer and in early autumn can be clearly seen. The water levels lower than $50 \mathrm{~cm}$ beneath the ground surface were observed for nearly 60 days of continuous period in August and September. The lowest level was observed 30 September and equals $71.3 \mathrm{~cm}$ below ground surface. This big lowering is more characteristic for terrains covered by Magnocaricion vegetation than sedgemoss vegetation. Water levels characteristic for Bagno Lawki site can be partly responsible for ongoing changes in vegetation type on this area.

Hydrological conditions of wetland vegetation habitats presented in this paper were compared with results published by other researchers (Table 3). Compiled results are not much different from each other within habitats of the same vegetation types. Thus allows generalizing the results interpretation and applying the results not only to Biebrza National Park locally but for habitats of vegetation types generally.

\section{Nutrients in vegetation}

Among five studied sites we have found that three are phosphorus limited $(C$. lasiocarpae, $C$. elatae mossy variant and Molinion meadow) and two are nitrogen limited (C. elatae and C. gracilis) (Figs 5 and 6). Molinion vegetation shows the highest P-limitation among considered in this paper. In Kuligi site $\mathrm{N}$ : $\mathrm{P}$ differs from 16.30 to 25.47 , and mean value equals 21.04 which shows strong P-limitation. Additionally low phosphorus concentrations are characteristic for vegetation covering this area (minimum: 0.52, maximum: 0.87, mean

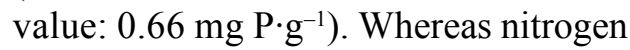
concentrations are ones from the highest among considered sites. Nitrogen concentrations in leaving part of biomass 
TABLE 3. Comparative setting-up of water levels characteristic assessed in presented study (values in italic font) with characteristics from other studies (minus for water levels beneath ground surface)

\begin{tabular}{|c|c|c|c|c|c|c|}
\hline \multirow{3}{*}{$\begin{array}{l}\text { Value } \\
\text { Min }(\mathrm{cm})\end{array}$} & \multicolumn{6}{|c|}{ Vegetation type } \\
\hline & \multicolumn{2}{|c|}{ Magnocaricion } & \multicolumn{2}{|c|}{$\begin{array}{c}\text { Scheuchzerio-Caricetea } \\
\text { nigrae }\end{array}$} & \multicolumn{2}{|c|}{ Molinio-Arrhenatheretea } \\
\hline & $\begin{array}{l}-98.5 \\
-95.5\end{array}$ & $\begin{array}{r}-24 \text { to }-32 \mathrm{~b} \\
-52.0 \pm 3.0 \mathrm{i} \\
-55.0 \mathrm{j} \\
-33.5 \mathrm{k}\end{array}$ & $\begin{array}{l}-71.3 \\
-45.3\end{array}$ & $\begin{array}{r}-8.0 \pm 3.0 \mathrm{i} \\
-33.0 \pm 6.0 \mathrm{i} \\
-38.0 \mathrm{j} \\
-11.0 \mathrm{k}\end{array}$ & -98.5 & $-98.0 \mathrm{k}$ \\
\hline $\operatorname{Max}(\mathrm{cm})$ & $\begin{array}{l}43.5 \\
67.4\end{array}$ & $\begin{array}{r}20-60 \mathrm{~b} \\
27.0 \pm 6.0 \mathrm{~h} \\
53.0 \mathrm{j} \\
55.5 \mathrm{k}\end{array}$ & $\begin{array}{r}-3.2 \\
5.6\end{array}$ & $\begin{array}{r}19.0 \pm 3.0 \mathrm{~h} \\
0.0 \pm 3.0 \mathrm{~h} \\
19.0 \mathrm{j} \\
14.0 \mathrm{k}\end{array}$ & 9.8 & $0.0 \mathrm{k}$ \\
\hline Average $(\mathrm{cm})$ & $\begin{array}{r}-10.4 \\
4.3\end{array}$ & $\begin{array}{r}-0.5 \mathrm{a} \\
54.8 \pm 6.8 \mathrm{c} \\
4.0 \pm 6.5 \mathrm{~d} \\
5.0 \pm 2.0 \mathrm{f} \\
5.0 \pm 5.0 \mathrm{~g} \\
6.5 \mathrm{k} \\
\end{array}$ & $\begin{array}{r}-26.2 \\
-8.8\end{array}$ & $\begin{array}{r}0.0 \mathrm{a} \\
-3.5 \pm 6.2 \mathrm{c} \\
2.2 \pm 3.8 \mathrm{~d} \\
-25.5 \mathrm{e} \\
4.0 \mathrm{k}\end{array}$ & -27.9 & $\begin{array}{r}-23.5 \mathrm{e} \\
-19.0 \mathrm{e} \\
0.0 \pm 6.0 \mathrm{f} \\
-40.0 \pm 15.0 \mathrm{~g} \\
-59.5 \mathrm{k}\end{array}$ \\
\hline
\end{tabular}

a - Bootsma and Wassen 1996 (median, Caricetum lasiocarpae - Northwestern Overijseel in the Netherlands, Caricetum elatae - Biebrza); b - Wassen et al. 2002 (average values, Biebrza); c, d - Wassen 1995 (average values \pm SD, c - spring, d - summer, Biebrza); e - El-Kahloun et al. 2005 (Molinietum caeruleae various sites, Biebrza NP); f, g - Olde Venterink et al. 2000 (average values \pm SD, Dommel river valley in the Netherlands and Zwarte Beek river valley in Belgium, $g$ - spring); $h, i-$ Wassen et al. 1998 (average values \pm SD, Biebrza NP, h - April, i - July, Caricetum lasiocarpae - various sites); j - de Mars et al. 1996 (extreme values, Biebrza NP); k - Oświt 1991 (average values, Biebrza NP).

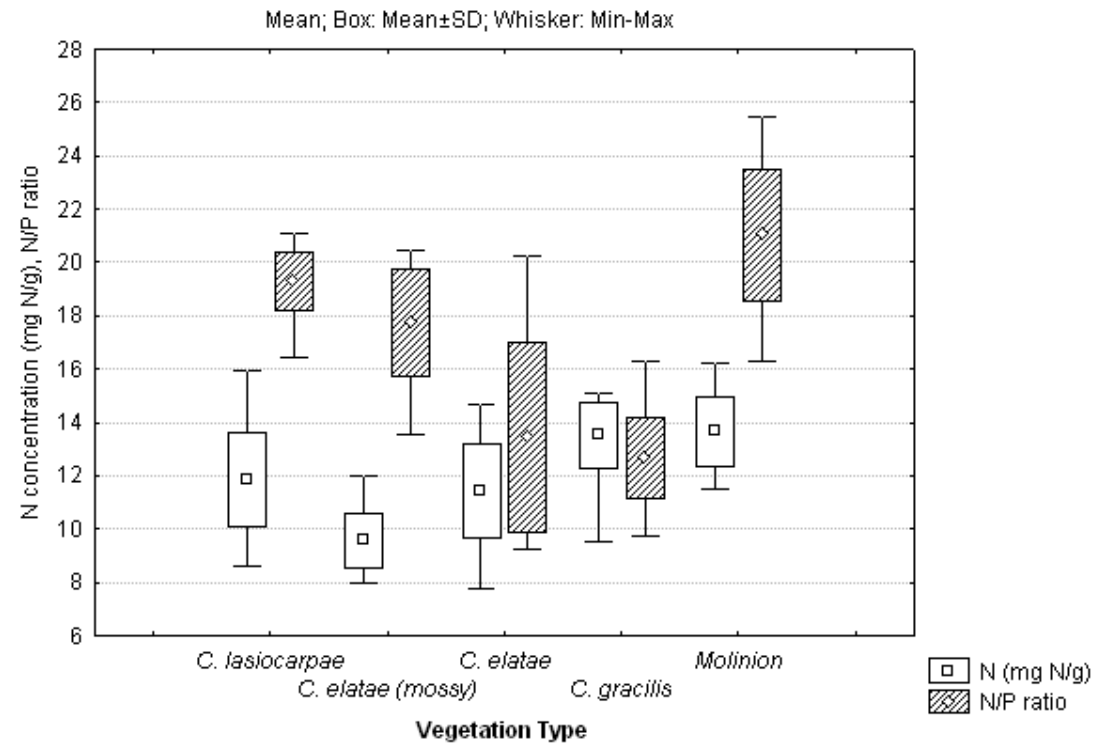

FIGURE 5. Nitrogen and phosphorus ratios and nitrogen concentrations in living part of biomass in chosen plant communities 


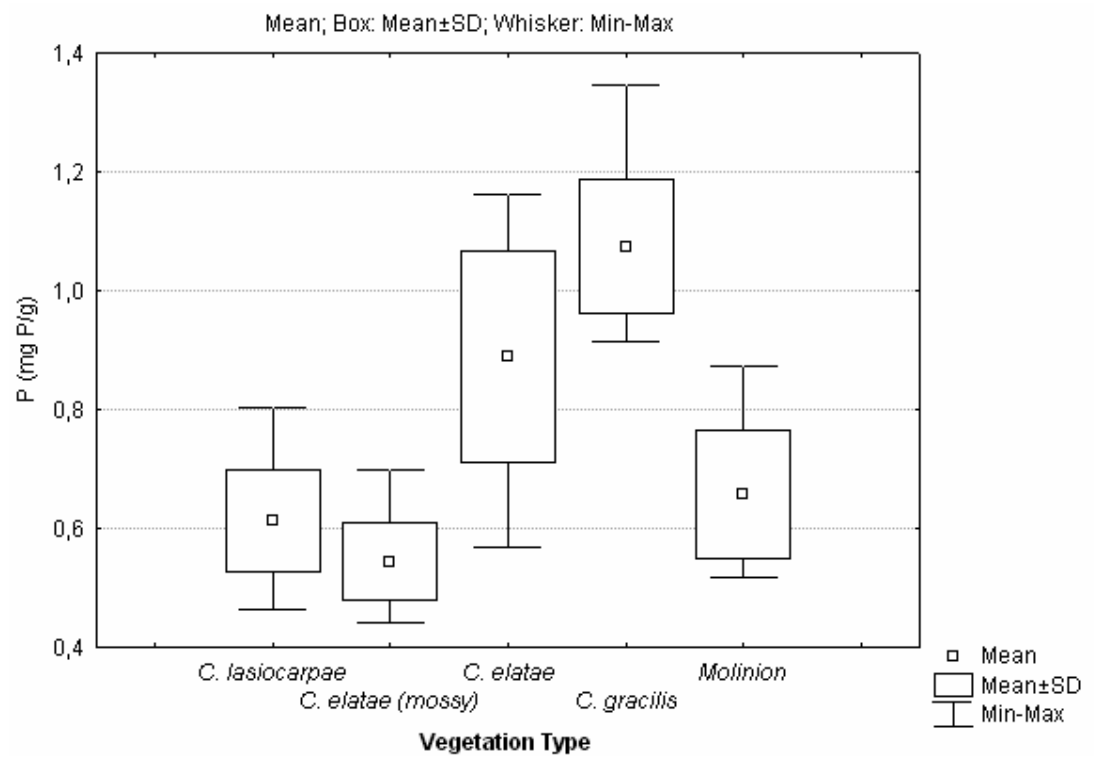

FIGURE 6. Phosphorus concentrations in living part of biomass in chosen plant communities

differs from 11.50 to $16.21 \mathrm{mg} \mathrm{N} \cdot \mathrm{g}^{-1}$ of dry matter, with mean value of $13.66 \mathrm{mg} \mathrm{N} \cdot \mathrm{g}^{-1}$.

Scheuchzerio-Caricetea nigrae vegetation present in Lipsk site is also P limited vegetation (mean $\mathrm{N}$ : P equals 19.3). We have found also low phosphorus and comparatively low nitrogen concentrations as a characteristic for vegetation covering this area. Nitrogen concentrations in leaving part of biomass differs from 8.62 to $15.96 \mathrm{mg} \mathrm{N} \cdot \mathrm{g}^{-1}$, with mean value of $11.84 \mathrm{mg} \mathrm{N} \cdot \mathrm{g}^{-1}$. And phosphorus concentrations differs from 0.46 to $0.80 \mathrm{mg} \mathrm{P} \cdot \mathrm{g}^{-1}$ of dry matter (mean value is $0.61 \mathrm{mg} \mathrm{P} \cdot \mathrm{g}^{-1}$ ).

Mossy variant of Caricetum elatae present in Bagno Lawki site shows characteristic nitrogen and phosphorus concentrations for the Scheuchzerio-Caricetea nigrae vegetation. For this vegetation we observed the lowest con- centrations of nitrogen and phosphorus among analysed in this paper. Mean nitrogen concentration equals only $9.58 \mathrm{mg} \mathrm{N} \cdot \mathrm{g}^{-1}$, and extremes differ from 7.97 to $11.97 \mathrm{mg} \mathrm{N} \cdot \mathrm{g}^{-1}$ of dry matter. Phosphorus concentrations differ from 0.44 to $0.70 \mathrm{mg} \mathrm{P} \cdot \mathrm{g}^{-1}$ of dry matter (mean value is: $\left.0.54 \mathrm{mg} \mathrm{P} \cdot \mathrm{g}^{-1}\right)$. The $\mathrm{N}: \mathrm{P}$ with mean value 17.75 indicates that vegetation in Bagno Lawki site is P-limited.

In Mścichy site we have found the highest concentrations of phosphorus and comparatively low nitrogen concentrations in biomass (however ones from the highest among considered vegetation types). Concentration of phosphorus in vegetation differs along the site from 0.91 to $1.35 \mathrm{mg} \mathrm{P} \cdot \mathrm{g}^{-1}$ of dry

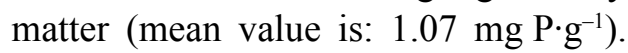
The lowest nitrogen concentration in dried living part of vegetation equals $9.51 \mathrm{mg} \mathrm{N} \cdot \mathrm{g}^{-1}$, thehighest: $15.11 \mathrm{mg} \mathrm{N} \cdot \mathrm{g}^{-1}$, 
and mean value: $13.52 \mathrm{mg} \mathrm{N} \cdot \mathrm{g}^{-1}$. The $\mathrm{N}$ : $\mathrm{P}$ indicating nitrogen limitation differs in Mścichy site from 9.75 to 16.33 , with mean value of 12.67 .

Along the Olszowa Droga site we observed high diversification of nitrogen and phosphorus concentrations and high diversification of the $\mathrm{N}: \mathrm{P}$. This situation can be caused by using this area by local farmers which can disturb natural character of habitats. A cattle grazing is common in this area and can lead to disturbance of natural $\mathrm{N}, \mathrm{P}$ concentrations by excrements. Although, Cricetum elatae vegetation present in this site shows $\mathrm{N}$-limitation the $\mathrm{N}$ : $\mathrm{P}$ with mean value of 13.43). We can find here high concentration of phosphorus (mean value: $0.89 \mathrm{mg} \mathrm{P} \cdot \mathrm{g}^{-1}$ ) and comparatively low nitrogen concentrations (mean value: $11.43 \mathrm{mg} \mathrm{N} \cdot \mathrm{g}^{-1}$ ).

\section{CONCLUSIONS}

Presented paper shows recognition of wetland vegetation habitats characteristic (hydrological conditions) in relation to vegetation productivity and nutrients content in biomass. Conducting analysis on the area of undisturbed Biebrza National Park allows using collected dataset as reference information, highly valuable for e.g. conservation or restoration projects, where knowledge about interactions between main factors forming wetlands habitats is essential.

Magnocaricion vegetation, fed by rivers water, shows high productivity (up to $1222.28 \mathrm{~g} \cdot \mathrm{m}^{-2}$ of living part of biomass). Compared with the other vegetation types, this vegetation shows higher nutrient concentrations. The $\mathrm{N}: \mathrm{P}$ indicate $\mathrm{N}$-limitation. This is coherent with the general assumption that the most flooded vegetation is limited by nitrogen (Wassen 1995, Olde Venterink and Wassen 2000, El-Kahloun et al. 2003, El-Kahloun et al. 2005). Habitats of tall sedges communities such as Caricetum gracilis and Caricetum elatae were characterized by high and long lasting inundations. Soils in these sites are characterized by average degree of decomposition (Banaszuk 2000). Comparing this information with presence of deep lowering of groundwater table, allow us to assume that this vegetation type sustain in good condition on soils with wide moisture spectrum with comparatively large resistance to overdrying.

Vegetation present in Bagno Ławki site was classified as a Caricetum elatae, despite that the results of cluster analysis and large participation of sedge-moss species in vegetation relevés, shows strict connection to plant communities of Scheuchzerio-Caricetea nigrae. Present plant community is transformed from Caricetum lasiocarpae, probably temporary but nowadays large participation of Carex elata cause classification of this plant community to Magnocaricion vegetation. Although classification, vegetation present in Bagno Ławki site should be considered as sedge-moss vegetation.

Molinio-Arrhenatheretea vegetation as well as Scheuchzerio-Caricetea nigrae vegetation is low productive (respectively 210.47 and $153.87 \mathrm{~g} \cdot \mathrm{m}^{-2}$ ). These two vegetation types are fed by groundwater, with relatively low amplitude of water levels changes, specially in Lipsk site. 
It is significant remark that even in dry periods the water table doesn't reach as low levels as in sites covered by Magnocaricion vegetation. In Molinion vegetation nutrient concentrations in living aboveground biomass shows low phosphorus and relatively high nitrogen concentrations. The $\mathrm{N}: \mathrm{P}$ (higher than 16.3) indicate a strong phosphorus limitation. In general, most P-limited sites are moderate to low productive. Studies conducted in the Netherlands, Belgium and Poland, Olde Venterik and Wassen (2000), El-Kahloun et al. (2003), El-Kahloun (2004) concluded that P-limitation was restricted to sites having a biomass less than $650 \mathrm{~g} \cdot \mathrm{m}^{-2}$, which comparing to our study is quite big production.

We concluded that both, drained fens and meadows, characterized by Scheuchzerio-Caricetea nigrae or Molinio-Arrhenatheretea vegetation, are subjected to phosphorus limitation, due to the low phosphorus input through groundwater. While the flooded Magnocaricion vegetation is strongly $\mathrm{N}$-limited probably due to the low mineralization rates in anaerobic conditions during long lasting inundations.

Moreover diagonal zonation of Biebrza National Park plays a role in river water influence on present vegetation and nutrients availability. On terrains, the nearest to the river, subjected to longer inundations and higher water levels, we observed the highest concentrations of nitrogen and phosphorus (Kardel et al. 2002), which led to increase in the biomass production. Also we observed increase of N-limitation on flooded areas, the nearest to the river. Concluding, we can clearly see that the vegetation composition and type of nutrient limitation is conditioned by hydrological regimes and type of water supply.

\section{Acknowledgments}

I would like to express my great appreciation to prof. Patrick Meire, the head of Ecosystem Management Research Group (ECOBE) for the opportunity to work with him and all the people whom I met at ECOBE for their valuable assistance in laboratory works with plant material analysis.

\section{REFERENCES}

BANASZUK H. 2000: Plan Ochrony Biebrzańskiego Parku Narodowego. Operat: Ochrona zasobów i walorów przyrody nieożywionej i gleb.

BOEYE D., VERHEYEN R.F. 1994: The relation between vegetation and soil chemistry gradients in a ground water discharge fen. Journal of Vegetation Science 5, 553-560.

BOOTSMA M.C., WASSEN M.J. 1996: Environmental conditions and fen vegetation in three lowland mires. Vegetatio 127, 173-189.

BRAUN-BLANQUET J. 1951: Pflanzenoziologie. Springer Erlang, Wien.

De MARS H., WASSEN M.J., OLDE VENTERINK H. 1996: Flooding and Groundwater Dynamics in Fens in Eastern Poland. In: Chemical and physical dynamics of fen hydroecology. Nederlandse Geografische Studies 203. PhD Thesis. Utrecht University, 19-34.

El-KAHLOUN M. 2004: Vegetation dynamics in P-limited rich fens. PhD Thesis. University of Antwerp.

El-KAHLOUN M., BOEYE D., Van HAESEBROECK V., VERHAGEN B. 2003: Differential recovery of above- and below-ground fen vegetation following fertilization. Journal of Vegetation Science 14: 451-458.

EL-KAHLOUN M., BOEYE D., VERHAGEN B., VAN HAESEBROECK V., 2000: A com- 
parison of the nutrient status of Molinia caerulea and neighbouring vegetation in a rich fen. Belg. Journ. Bot. 133 (1-2), 91-102.

EL-KAHLOUN M., GERARD M., MEIRE P., 2005: Effects of management and groundwater fluctuations on nutrients availability in two phosphorus-limited rich fens. In: W. Kotowski (Ed.) Wethydro Center of Excelence in Wetland Hydrology. Anthropogenic influence on wetlands biodiversity and sustainable management of wetlands. WETHYDRO Series, Part 3, 35-47.

GÜSEWELL S., KOERSELMAN W., 2002: Variation in nitrogen and phosphorus concentrations of wetland plants. Perspectives in Plant Ecology, Evolution and Systematics 5, 37-61.

HOUBA V.J.G., Van Der LEE J.J., NOVOZAMSKY I., WALLINGA I. 1989: Soil and plant analysis, a series of syllabi. Part 5. Soil analysis procedures. Agricultural University, Wageningen.

KARDEL I., IGNAR S., OKRUSZKO T. 2002: Method for identification of non-point pollution sources originating from mineralized hydrogenic soils. Annals of Warsaw Agriculture University. Land Reclamation 33, 109-118.

KOERSELMAN W., BAKKER S.A., BLOM M. 1990: Nitrogen, phosphorus and potassium budgets for two small fens surrounded by heavily fertilized pastures. Journal of Ecology 78, 428-442.

KOERSELMAN W., MEULEMAN A.F.M., 1996: The vegetation N:P Ratio: a new tool to detect the nature of nutrient limitation. Journal of Applied Ecology 33, 1441-1450.

KOERSELMAN W., Van KERKHOVEN M.B., VERHOEVEN J.T.A. 1993: Release of inorganic $\mathrm{N}, \mathrm{P}$, and $\mathrm{K}$ in peat soils: effect of temperature, water chemistry, and water level. Biogeochemistry 20, 63-81.

MATUSZKIEWICZ A.J., GŁOWACKA I., JAKUBOWSKI W., KAMIŃSKI J., MYŚLIŃSKI G., SOBCZYŃSKI L. 2000: Plan Ochrony Biebrzańskiego Parku Narodowego. Operat: Ochrona lądowych ekosystemów nieleśnych (projekt). Maszynopis. NFOŚiGW. BPN, Warszawa.
OLDE VENTERINK H., KARDEL I., KOTOWSKI W., PEETERS W., WASSEN M.J. 2009: Long-term effects of drainage and hay-removal on nutrient dynamics and limitation in the Biebrza mires, Poland. Biogeochemistry 93, 235-252.

OLDE VENTERINK H., WASSEN M.J. 2000: A triaxal NPK diagram to distinguish the type of nutrient limitation in herbaceous wetlands. In: S. Güsewell, J. Verhoeven, W. Koerselman (Eds). Nutrient Limitation and Species Diversity of Wet and Dry Herbaceous vegetation. Workshop Proceeding, Department of Plant Ecology and Evolutionary Biology, Utrecht University, 5.

OLDE VENTERINK H., WASSEN M.J., BELGERS D.M., VERHOEVEN J.T.A. 2000: Environmental control on biomass production and species density in meadows and fens. In: Nitrogen, Phosphorus and Potassium Flows Controlling Plant Productivity and Species Richness. Eutrophication and Nature Management in Fens and Meadows. PhD Thesis. Utrecht University, 69-80.

OŚWIT J. 1991: Roślinność i siedliska zabagnionych dolin rzecznych na tle warunków wodnych. Rocznik Nauk Rolniczych. Seria D. Monografie. Tom 221. PAN. Wydział Nauk Rolnych i Leśnych. PWN, Warszawa.

PAŁCZYŃSKI A. 1979: Mapy zbiorowisk roślinnych doliny Biebrzy. Stan 1977/79. 1:25000.

SCHRAUTZERA J., SIVAL F., BREUERA M., RUNHAARC H., FICHTNERD A. 2013: Characterizing and evaluating successional pathways of fen degradation and restoration. Ecological Indicators 25, 108-120.

WASSEN M.J. 1995: Hydrology, water chemistry and nutrient accumulation in the Biebrza fens and floodplains (Poland). Wetlands Ecology and Management 3 (2), 125-137.

WASSEN M., BLEUTEN W., BOOTSMA M.C. 2002: Biebrza as geographical reference. $A n-$ nals of Warsaw Agriculture University. Land Reclamation 33, 27-47.

WASSEN M.J., Van der VLIET R.E., VERHOEVEN J.T.A. 1998. Nutrient limitation in the Biebrza fens and floodplain (Poland). Acta Botanica Nederlandica 47 (2), 241-253. 
Streszczenie: Dostępność substancji pokarmowych oraz warunki wodne wybranych ekosystemów bagiennych $w$ dolinie rzeki Biebrzy. Artykuł przedstawia wyniki badań warunków wodnych oraz dostępności substancji pokarmowych dla roślinności bagiennej w wybranych lokalizacjach w dolinie rzeki Biebrzy. Analizowane siedliska były porośnięte przez szuwary wielkoturzycowe $\mathrm{z}$ klasy Magnocaricion (Caricetum gracilis oraz Caricetum elatae), łąkę zmiennowilgotną z klasy Molinio-Arrhenatheretea (Molinietum caeruleae) oraz roślinność mszysto-turzycową z klasy Scheuchzerio-Caricetea nigrae (Caricetum lasiocarpae). Zanotowano ścisły związek między typem roślinności oraz reżimem hydrologicznym i rodzajem niedoboru substancji pokarmowych. Wzrost niskoproduktywnej roślinności z klas Molinio-Arrhenatheretea oraz Scheuchzerio-Caricetea nigrae zasilanej głównie wodami podziemnymi był ograniczony dostępnością fosforu, podczas gdy wysokoproduktywna roślinność z klasy Magnocaricion zasilana wodami rzecznymi podlegała niedoborom azotu. $\mathrm{Na}$ obszarze doliny rzeki Biebrzy zanotowano znaczne zróżnicowanie poziomów wód gruntowych i powierzchniowych w siedliskach występowania odmiennych typów roślinności. Siedliska roślinności z klasy Magnocaricion znajdujące się na obszarach zalewowych charakteryzują się znaczącymi zmianami poziomu wód oraz długotrwałymi zalewami. Na obszarach porośniętych przez roślinność z klasy Molinio-Arrhenatheretea zanotowa- no występowanie poziomów wód w większości nieprzekraczających poziomu gruntu. Roślinność z klasy Scheuchzerio-Caricetea nigrae występuje zaś na obszarach zasilanych wodami podziemnymi o małej zmienności poziomów wód.

Stowa kluczowe: mokradła, reżim hydrologiczny, zalewy, dostępność substancji pokarmowych, produktywność roślinności, typy roślinności

\section{MS. received November 2014}

\section{Authors' addresses:}

Mateusz Stelmaszczyk

Centrum Wodne, Zakład Hydrologii i Zakładów Wodnych SGGW

ul. Nowoursynowska 166, 02-787 Warszawa

Poland

e-mail: M.Stelmaszczyk@levis.sggw.waw.pl

Tomasz Okruszko

Zakład Hydrologii i Zasobów Wodnych

Katedra Inżynierii Wodnej SGGW

ul. Nowoursynowska 166, 02-787 Warszawa

Poland

Patrick Meire

Department of Biology, Ecosystem Management Research Group, University of Antwerp (UIA)

Universiteitsplein 1, B-2610 Wilrijk

Belgium 